\title{
Structural differences of amyloid- $\beta$ fibrils revealed by antibodies from phage display
}

\author{
Patrick Droste ${ }^{1,2}$, André Frenzel $^{1,3}$, Miriam Steinwand ${ }^{1,4}$, Thibaut Pelat ${ }^{5,6}$, Philippe Thullier ${ }^{5}$, Michael Hust ${ }^{1}$,
} Hilal Lashuel ${ }^{7^{*}}$ and Stefan Dübel ${ }^{1 *}$

\begin{abstract}
Background: Beside neurofibrillary tangles, amyloid plaques are the major histological hallmarks of Alzheimer's disease (AD) being composed of aggregated fibrils of $\beta$-amyloid $(A \beta)$. During the underlying fibrillogenic pathway, starting from a surplus of soluble $A \beta$ and leading to mature fibrils, multiple conformations of this peptide appear, including oligomers of various shapes and sizes. To further investigate the fibrillization of $\beta$-amyloid and to have tools at hand to monitor the distribution of aggregates in the brain or even act as disease modulators, it is essential to develop highly sensitive antibodies that can discriminate between diverse aggregates of $A \beta$.
\end{abstract}

Results: Here we report the generation and characterization of a variety of amyloid- $\beta$ specific human and human-like antibodies. Distinct fractions of monomers and oligomers of various sizes were separated by size exclusion chromatography (SEC) from A 442 peptides. These antigens were used for the generation of two A 42 specific immune scFv phage display libraries from macaque (Macaca fascicularis). Screening of these libraries as well as two naïve human phage display libraries resulted in multiple unique binders specific for amyloid- $\beta$. Three of the obtained antibodies target the N-terminal part of $A \beta 42$ although with varying epitopes, while another scFv binds to the a-helical central region of the peptide. The affinities of the antibodies to various A 342 aggregates as well as their ability to interfere with fibril formation and disaggregation of preformed fibrils were determined. Most significantly, one of the scFv is fibril-specific and can discriminate between two different fibril forms resulting from variations in the acidity of the milieu during fibrillogenesis.

Conclusion: We demonstrated that the approach of animal immunization and subsequent phage display based antibody selection is applicable to generate highly specific anti $\beta$-amyloid scFvs that are capable of accurately discriminating between minute conformational differences.

Keywords: Alzheimer's disease, A $\beta$, Abeta, Beta-amyloid, Phage display, Immune library, scFv

\section{Background}

Alzheimer's Disease is a slowly progressing, irreversible neurodegenerative disorder and the most prevalent cause of dementia in the elderly. With 7.7 million new cases every year and a survival time after diagnose of 7.1 years [1] the number of over 35 million people suffering as of 2012 is thought to be tripled by the year 2050 according to the world health organization (WHO). Accompanied

\footnotetext{
* Correspondence: hilal.lashuel@epfl.ch; s.duebel@tu-bs.de

${ }^{7}$ SV-BMI, Laboratory of Molecular and Chemical Biology of

Neurodegeneration, Brain Mind Institute, École Polytechnique Fédérale de

Lausanne, Station 19, 1015 Lausanne, Switzerland

${ }^{1}$ Technische Universität Braunschweig, Institute of Biochemistry,

Biotechnology and Bioinformatics, Spielmannstr.7, 38106 Braunschweig,

Germany

Full list of author information is available at the end of the article
}

by this, the annual cost generated by dementia, currently exceeding 600 billion $\$$, will most likely rise to more than 1,100 billion $\$$ within the next 15 years. It is the socioeconomic impact which lays the foundation for the urgent need of diagnostic and therapeutic tools in $\mathrm{AD}$ that target the disease and its progression at an early stage.

Histological hallmarks of AD are neurofibrillary tangles, comprised of hyperphosphorylated tau protein [2,3], and amyloid plaques that are composed of aggregated amyloid- $\beta$ peptides [4-6]. Amyloid- $\beta$ is regarded as the main culprit causing the neuropathology in $\mathrm{AD}$ and is released from the amyloid precursor protein by sequential cleavage with $\beta$ - and $\gamma$-secretases. This processing results in peptides of various amino acids (aa) in length with the majority being 40 aa (90\%) and 42 aa (10\%) long [7], hence 
the terminology $A \beta 40 / 42$. Changes in the metabolism of $\mathrm{A} \beta$ lead to an imbalance between elevated peptide production and decreased clearance from the brain, shifting the concentration and facilitating self aggregation of $\beta$ amyloid. Once a critical concentration is surpassed, the aggregation follows a nucleation-dependent polymerization process to form mature fibrils with various oligomeric intermediates along the way $[8,9]$. A multitude of diverse $A \beta$ aggregates has been identified, such as dimers $[10,11]$, heteromorphous oligomers [12-16], or protofibrils [17], that represent the last stage before the final transition into the fibril forms. Oligomers and protofibrils are widely regarded as the main toxic species in $\mathrm{AD}$ although the exact nature of the toxic entity - if such a form even exists [18] - has yet to be elucidated [19-25].

While on the one side researchers investigating how $A \beta$ contributes its toxicity to AD there are still other problems close at hand: up until today it is neither possible to diagnose the disease at an early, presymptomatic stage nor to treat patients beyond symptomatic relief, e.g. alleviating behavioral problems. The first symptoms emerge decades after neuronal changes occur [26]. Therefore the current diagnoses target progressed characteristics of the disease and are composed of various imaging methods such as $\mathrm{x}$-ray computed tomography $(\mathrm{CT})$ succeeded by magnetic resonance imaging (MRI) $[27,28]$ or positron emission tomography (PET) [29], additional to cognitive tests and the assessment of the patient's history regarding the worsening of cognition. Still, the combination of these tools does not result in an absolute accuracy of the diagnosis [30]. Additionally, to modify the progression of Alzheimer's disease it is essential to apply potential therapies at an early stage, long before amyloid plaques are formed [31]. Current treatment of AD involves acetylcholinesterase inhibitors (e.g. Donepezil) [32,33] and N-methyl-D-aspartate (NMDA) antagonists [34] to improve cognitive functionality, up until now only with remote success. For an early and accurate diagnosis of the disease as well as for a better treatment hypothesis, it is essential to get a deeper insight on the aggregation of amyloid- $\beta$.

During the transition from $A \beta$ monomer to fibrils, different conformational epitopes are expected to form, which may be used to differentiate between diverse aggregation forms of $A \beta$ using antibodies specifically recognizing these conformational epitopes. Phage display and immune libraries from macaque have been proven in the past to be an effective instrument for the generation of conformation specific antibodies, already providing a source of binders against targets like ricin [35], anthrax [36,37], bacterial surface proteins such as Crf2 from Aspergillus fumigatus [38], the Venezuelan equine encephalitis virus (VEEV) [39] and the western equine encephalitis virus (WEEV) [40] or botulinum neurotoxin A [41]. A further distinct advantage of NHP (non human primate) derived immune libraries is the very high degree of identity of the antibodies to human antibodies [42] allowing for very easy transition of the scFvs from diagnostic to therapeutic tools. Phage display antibody generation further allows to control the conditions and conformations during the very moment of binder selection, offering additional chances to steer antibody specificity towards conformational epitopes [43].

\section{Results}

\section{Antigen preparation (AB42)}

Fractions of $A \beta 42$ monomers, protofibrils and mature fibrils were prepared from synthetic $A \beta 42$ peptide to serve as antigens. Depending on the purification method, the separation via SEC with one column resulted either solely in pure monomers (Figure 1A) or a monomer fraction and a second peak representing a heterogeneous mixture of different sized oligomers, namely protofibrils (Figure 1B). These protofibrils range between $15 \mathrm{kDa}$ and $500 \mathrm{kDa}$ and display various forms and morphologies, with diameters of $8-10 \mathrm{~nm}$ and a length of up to $200 \mathrm{~nm}$. Protofibrils were further separated by two SEC columns connected in series to obtain smaller or larger oligomers (Figure 1C). Earlier eluting fractions include filaments significantly larger than $200 \mathrm{~nm}$ (LO = large oligomers) while later eluting fractions consist predominantly of short fibrils $(\mathrm{MO}=$ medium oligomers) of up to $100 \mathrm{~nm}$ and small, circular aggregates ( $\mathrm{SO}=$ small oligomers) that can be smaller than $10 \mathrm{~nm}$. Mature fibrils are generated from monomers by incubation at $37^{\circ} \mathrm{C}$ for $24 \mathrm{~h}$ and $300 \mathrm{rpm}$. We observed the same distribution of aggregates among the fractions with two different running buffers: $10 \mathrm{mM}$ Tris- $\mathrm{HCl}$, $\mathrm{pH} 7.4$ or $100 \mathrm{mM} \mathrm{Na-Borate,} \mathrm{pH}$ 8.6. These running buffers were chosen depending on the later purpose of the antigen. $A \beta 42$ in $10 \mathrm{mM}$ Tris buffer cannot be used for amine coupling of the antigen (e.g. in SPR experiments) while $\mathrm{A} \beta 42$ in $10 \mathrm{mM}$ Tris- $\mathrm{HCl}, \mathrm{pH} 7.4$ is more suitable for immunization.

\section{Immunization and antibody phage display library construction}

Late fractions of SEC purified A $\beta 42$ oligomers (SO) were used for the immunization as well as for measuring the immune response by enzyme linked immunosorbent assay (ELISA). Ten days after the fifth boost, the antibody titer was determined to be 1 per 80,000 . Nine weeks later a sixth boost was administered. PCR products of antibody genes were collected six and nine days after the last boost. The DNA fragments were pooled and subcloned into pGemT, resulting in a total of $2.7^{*} 10^{6}$ and $4.4^{*} 10^{5}$ individual clones for $V_{H}$ and $V_{L}$ respectively. pHAL35, a modified version of the pHAL14 phage display vector, was used for phage display library construction by two consecutive cloning steps. First, $\mathrm{V}_{\mathrm{L}}$ gene fragments for the $\mathrm{\kappa}$ (kappa) 


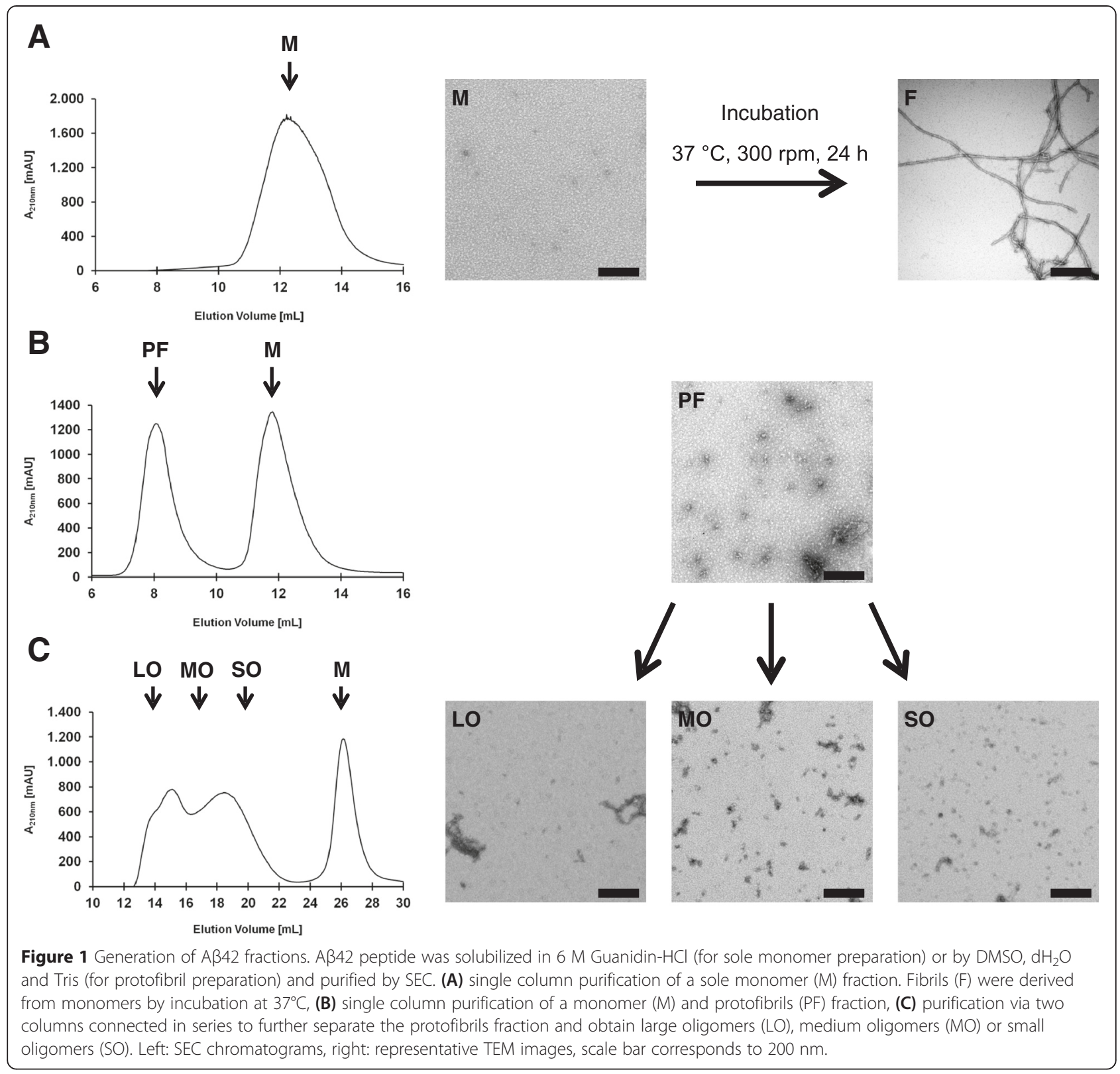

and $\lambda$ (lambda) were inserted using the restriction sites $M l u \mathrm{I}$ and NotI followed by cloning of the $\mathrm{V}_{\mathrm{H}}$ gene fragments via SfiI and HindIII. The final libraries comprised a total of $2.9^{*} 10^{7}$ individual clones. The insert rates were determined by colony-PCR to be $60 \%$ for the kappa library and $80 \%$ for the lambda library. Both libraries were packaged using M13K07 as helperphage.

\section{Isolation of Amyloid- $\beta$ specific scFvs}

Multi-step pannings, with or without competition with unwanted forms of A 42 antigen (e.g. panning on immobilized fibrils with soluble monomers added for competition), were carried out to generate antibodies with diverse specificities against Amyloid- $\beta$. In addition to the two macaque IgG derived immune phage display libraries, two IgM derived naïve human phage display libraries HAL7/8 [44] were employed. From a total of 54 pannings, 6088 antibody clones were analyzed by ELISA and 612 hits were identified. Eight unique monoclonal antibodies with individual sequences, named PaD97-D6 from the naïve human libraries and PaD172-F8, PaD172-F12, PaD213A5, PaD218-E6, PaD233-E5, PaD235-D2 and PaD236-H2 from the immune libraries were selected (Table 1) based on their specificity, their above average absorption or because of their high signal to noise ratio in the screening ELISAs. All eight antibodies were produced as scFvs and scFv-Fc fusions (Yumabs) [45] in mammalian cell culture. PaD172-F8, PaD218-E6 and PaD235-D2 could not 
Table 1 Antibody pannings

\begin{tabular}{lrrr}
\hline & \multicolumn{3}{c}{ Libraries } \\
\cline { 2 - 3 } & HAL7/8 & A $\boldsymbol{\beta}$ libraries $(\boldsymbol{\lambda}+\mathbf{K})$ & Total \\
\hline Number of pannings & 28 & 26 & 54 \\
Clones investigated & 3236 & 2852 & 6088 \\
Hits & 2 & 610 & 612 \\
Unique binders & 1 & 7 & 8 \\
\hline
\end{tabular}

be produced properly and disregarded for the following experiments.

Yumabs consist of a human IgG1 Fc part that is linked with two scFvs instead of Fab-fragments.

The specificity of PaD97-D6, PaD172-F12, PaD213-A5, PaD233-E5 and PaD236-H2 was initially verified on different forms of $\mathrm{A} \beta 42$, i.e. monomers, small, medium and large oligomers and mature fibrils by ELISA (Figure 2). Here, all antibodies except PaD213-A5 showed no predominant binding to any distinct form. Only PaD213-A5 exhibited specificity towards $A \beta 42$ fibrils. Additionally, binding to fibrils of other amyloidogenic peptides was evaluated in the same manner. These peptides included mature fibrils of A $\beta 40, \alpha$-synuclein, Huntingtin ( $\mathrm{Htt}$ (aa105-138)) and fibrils of Tau (isoform F), the K18 domain and the PHF6 domain of Tau. PaD97-D6 exhibited some cross reactivity with Tau fibrils of the isoform $\mathrm{F}$ (data not shown).

\section{PaD213-A5 differentiates between various $A \beta 42$ fibrils}

A $\beta 42$ peptide was purified in two different running buffers, $10 \mathrm{mM}$ Tris- $\mathrm{HCl}$, pH 7.4 or $100 \mathrm{mM} \mathrm{Na-Borate,}$ $\mathrm{pH}$ 8.6, depending on its later application. Repeated immunological assays elucidated the selectivity of PaD213A5 towards a distinct form of A 442 fibrils. This antibody exhibited no affinity to mature fibrils produced in Tris- $\mathrm{HCl}$ buffer while on the other hand binding to fibrils generated in Na-Borate buffer (Figure 3A). TEM investigation revealed major differences in the composition of the fibrils. Na-Borate derived fibrils exhibited a compact bundle of 4-8 individual fibrils twisted helically every 130-150 nm (Figure 3B) while Tris derived fibrils consisted of one discrete fibril with a helical twist around its axis about every $50 \mathrm{~nm}$ (Figure 3C).

\section{All antibodies detect different epitopes}

The determination of the epitope of the Amyloid- $\beta$ specific antibodies was performed using a peptide spot membrane (Figure 4). Each spot on the membrane consisted of 15 AA of the A $\beta 42$ peptide with an offset of 1 AA. Epitope mapping was performed with all antibodies to verify binding to linear epitopes. No binding was detected with PaD213-A5 since it is fibril specific, i.e. detecting a conformational epitope. PaD97-D6, PaD172-F12 and $\mathrm{PaD} 236-\mathrm{H} 2$ bound to the $\mathrm{N}$-terminus of $\mathrm{A} \beta 42$ albeit differing in the exact epitope with position 1 to 13 for PaD97-D6 ("DAEFRHDSGYEVH"), position 4 to 13 for PaD172-F12 ("FRHDSGYEVH") and position 5 to 13 for PaD236-H2 ("RHDSGYEVH"). A more precise determination of the epitopes for these three antibodies was impeded by the spot sizes of $15 \mathrm{AA}$ in length. PaD233-E5 bound to the central region of $A \beta 42$. Here, the exact epitope was more narrowly determined by amino acids 17 to 22 ("LVFFAE") (Figure 5).

\section{Affinity determination of the scFvs by surface plasmon resonance (SPR)}

Affinity determination was carried out on various Amyloid$\beta$ monomers, protofibrils and fibrils, via BIAcore ${ }^{\mathrm{TM}}$ with different antibody concentrations and resulted in $K_{D}$ values in the micro- to nanomolar range (Table 2). The antibodies targeting the aminoterminal end of $\mathrm{A} \beta 42$ and each antibody, PaD97-D6, PaD172-F12 and PaD236-H2, exhibited similar affinities towards all three forms of antigen. In contrast, $\mathrm{PaD} 233$-E5 which binds to the core region of $\mathrm{A} \beta 42$ shows an 100-fold elevated affinity to $A \beta 42$ monomers, with a $K_{D}$ of $10 \mathrm{nM}$, when compared to protofibrils and fibrils. PaD213-A5 bound solely to $A \beta 42$ fibrils with a $K_{D}$ of $36 \mu \mathrm{M}$.

\section{Yumabs inhibit $A \beta 42$ fibrillogenesis in a concentration dependent manner}

When binding to $A \beta 42$ monomers, an inhibitory effect of the antibodies on fibril formation could be possible. We tested the effect of all antibodies on the formation of mature $A \beta 42$ fibrils from pure monomers by visualizing potential fibrils using transmission electron microscopy (TEM) and measuring Thioflavin $\mathrm{T}$ (ThT) fluorescence. ThT is a dye that, upon binding to amyloid fibrils, exhibits fluorescence. Thus it allows for the assessment of fibril formation, which was investigated in this study by combining part of the sample with ThT stock solution every six hours during the first $24 \mathrm{~h}$, every $12 \mathrm{~h}$ during the next $24 \mathrm{~h}$ and with a final checkpoint after $96 \mathrm{~h}$ (Figure 6).

Bivalent scFv-Fc antibodies (Yumabs) were able to interfere with fibril formation at a substoichiometric level for PaD97-D6, PaD233-E5 and PaD236-H2 (Figure 6). The influence is most notable for PaD233-E5, the antibody targeting the central $\alpha$-helical region of $A \beta 42$. Addition of $4 \mu \mathrm{M}$ scFv-Fc antibody to $5 \mu \mathrm{M}$ A $\beta 42$ monomers resulted in a reduction in ThT fluorescence of about $25 \%$ for PaD97-D6, nearly 50\% for PaD236-H2 and even more elevated forPaD233-E5 after $96 \mathrm{~h}$ of incubation (Figure 6). Comparison with $\mathrm{PaD} 213-\mathrm{A} 5$ or the negative control $\mathrm{scFv}$-Fc antibody indicates that this effect is not contributed to antibody concentration or design. Interestingly, $\mathrm{PaD172}-\mathrm{F} 12$, also directed against the N-terminal end of A 442 like PaD97-D6 and PaD236-H2, did not show an inhibitory effect. 

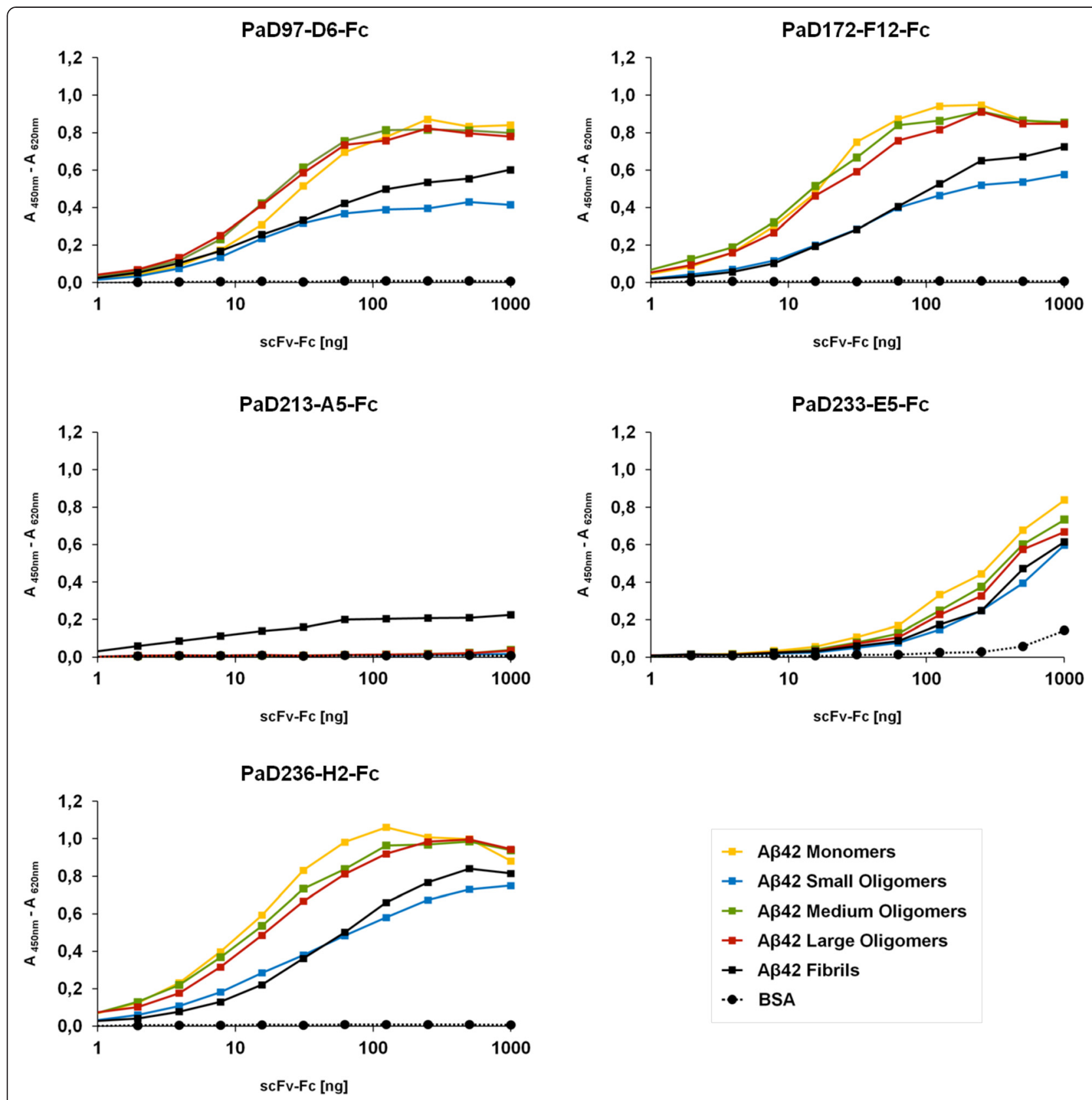

Figure 2 Specificity determination of scFv-Fc antibodies on $100 \mathrm{ng}$ of Aß42 monomers (yellow), small oligomers (blue), medium oligomers (green), large oligomers (red), fibrils (black) or BSA (dotted black). Dilutions of scFv-Fc antibodies were applied and detected using a peroxidase-labeled goat anti-human antibody recognizing the Fc fragment $(1: 35,000)$.

The reverse mechanism, a disintegration of preformed fibrils by antibody addition, was evaluated by ThT reading and TEM analysis as well. No antibody mediated disintegration of mature fibrils (data not shown).

\section{Discussion}

A 442 oligomers were chosen for the immunization of the NHP due to their reported elevated toxicity, making them a potential target for immunotherapy. Using the immune libraries and two previously established human naïve libraries [32] in a multistep panning, we created numerous antibody fragments specific for $\beta$-amyloid with an interesting spectrum of different binding properties.

The initial validation utilizing titration ELISAs demonstrated antibody specificity towards either form of $A \beta 42$ aggregates but no predominant preference for PaD97-D6, PaD172-F12, PaD233-E5 or PaD236-H2. Epitope mapping further revealed that three of these four antibodies detect 

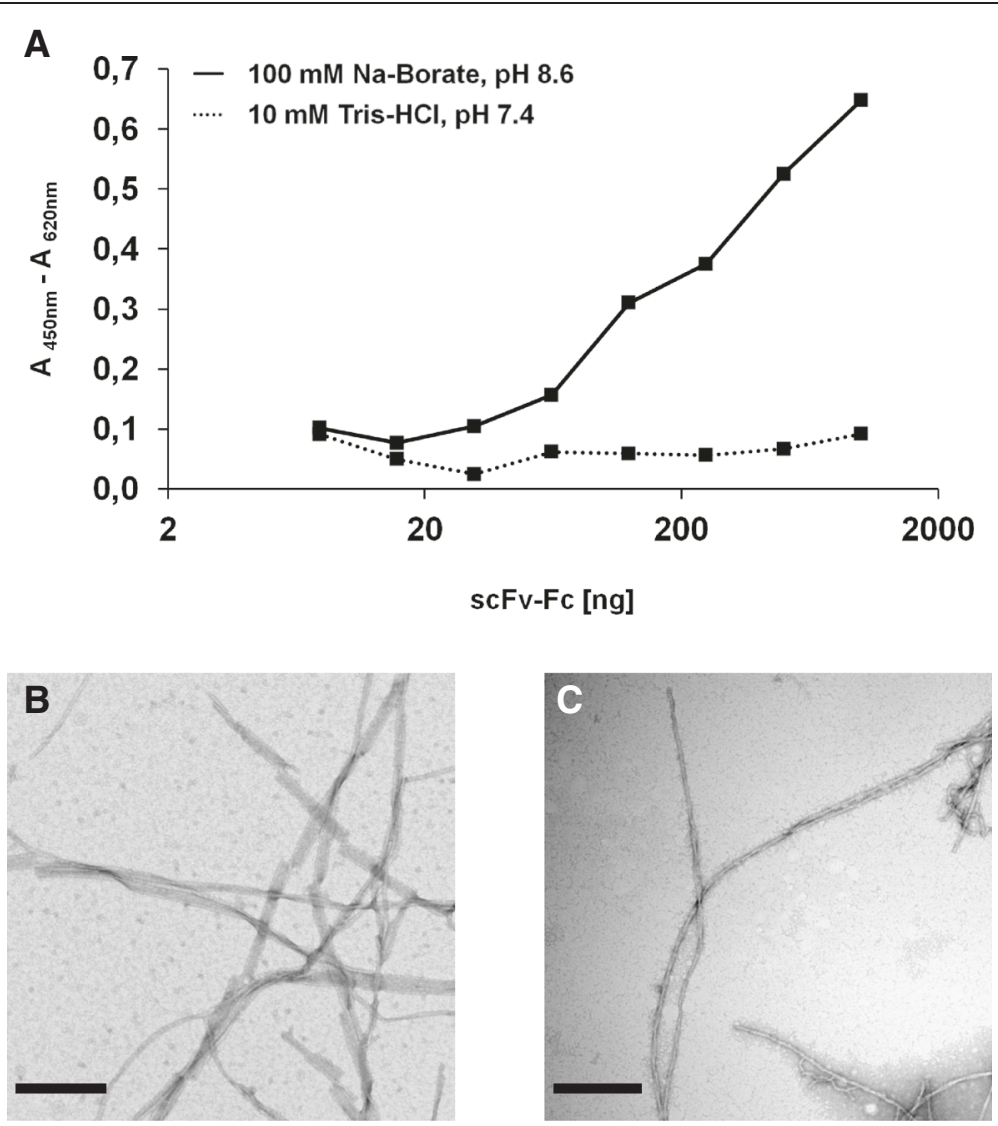

Figure 3 PaD213-A5 discriminates between different A 42 fibrils. A, titration ELISA of PaD213-A5 on different kinds of A 342 fibrils. Plates were coated with 100 ng of Aß42 fibrils from 100 mM Na-Borate, pH 8.6 (solid line) or 10 mM Tris-HCl, pH 7.4 (dotted line). Bound ScFv-Fc antibodies were detected using a peroxidase-labeled goat anti-human antibody recognizing the Fc fragment $(1: 35,000)$. Right: representative TEM images of Aß42 fibrils obtained from monomers purified in (B) $100 \mathrm{mM} \mathrm{Na-Borate,} \mathrm{pH} 8.6$ or (C) $10 \mathrm{mM}$ Tris-HCl, pH 7.4, the scale bar corresponds to $200 \mathrm{~nm}$.

the N-terminal part of A $\beta 42$ whereas PaD233-E5 binds to the central region. This is consistent with previous findings that the amino-terminal region of A $\beta 42$ is immunodominant in human [46], NHP [47] as well as in dog [48], mouse [49] and rabbit [50] explaining the quantity of antibodies and antibody fragments directed against this part of the peptide in this work and previous studies [49,51-55], with Bapineuzumab being the most prominent one. Solely PaD213-A5 demonstrated a high selectivity towards $\mathrm{A} \beta 42$ fibrils and did not bind to any other form of A $\beta 42$. Remarkably, PaD213-A5 was able to even discriminate between two different $\mathrm{A} \beta 42$ fibril preparations, depending whether the amyloid- $\beta$ peptide was purified in $10 \mathrm{mM}$ Tris- $\mathrm{HCl} / \mathrm{pH} 7.4$ or in $100 \mathrm{mM} \mathrm{Na}$ Borate/pH 8.6.

Meinhardt et al. [56] already described other preparation dependent polymorphisms in A $\beta 40$ fibrils. Based on their findings, it seems likely that the difference in the acidity of the buffers contributes to a morphological change in the fibril structure, a hypothesis that is supported by our TEM analysis. It can be hypothesized that
PaD213-A5 distinguishes between both types of fibrils through the detection of a conformational epitope which may well be dependent on the helical twist angle or the interspace distances between two single strands that make up the mature $\beta$-amyloid fibril. While there are antibodies and polyclonal sera that are fibril specific [57-59] the specificity observed here was not reported for any other known antibody. It remains to evaluated whether these structural differences have any significance in vivo.

To investigate the antibodies for a potential application as disease modulators, we assessed their impact on the fibrillization of $\mathrm{A} \beta 42$ monomers in vitro. The fibrillogenesis of $A \beta 42$ is a nucleation-dependent polymerization process [8]. When a certain concentration threshold of monomers is surpassed small aggregates termed "nuclei" accrue and polymerization starts. These nuclei are elongated by addition of monomers forming larger aggregates and ultimately fibrils. It has been previously shown that antibodies targeting the N-terminal end of amyloid- $\beta$ exhibit an inhibitory effect on the fibrillogenesis [60-63]. With the majority of our antibodies recognizing $\mathrm{A} \beta 42$ monomers 


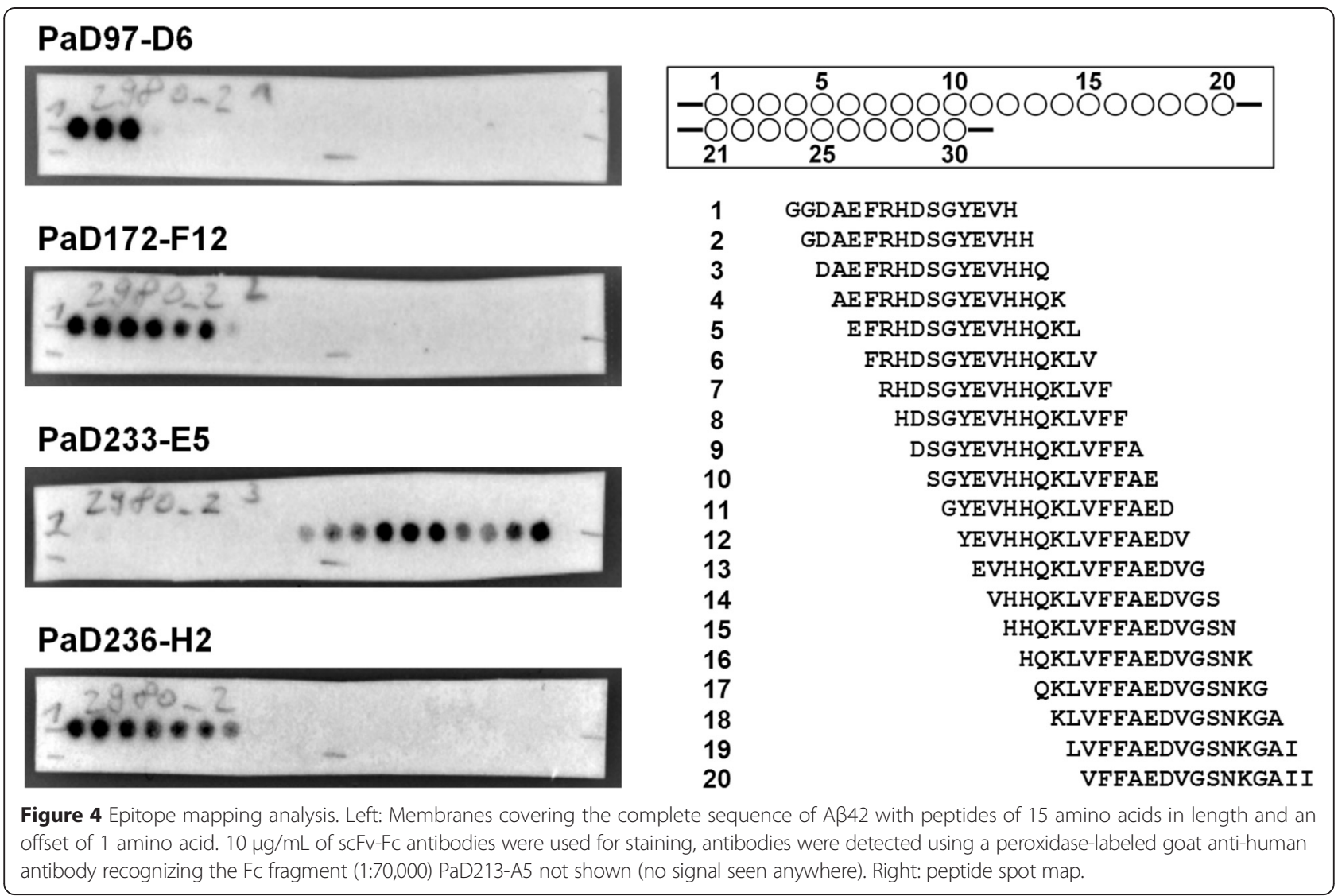

this gives rise to the idea that they can intervene in the initial aggregation by preventing interactions of $\beta$-amyloid peptides thus retarding or even inhibiting fibril formation [64].

PaD97-D6 and PaD236-H2 demonstrate a concentration dependent retardation of fibril formation resulting in shorter fibrils and an overall stronger appearance of unstructured aggregates. They do not prevent fibrillization entirely, which suggests a steric hindrance during monomer-monomer attachment [61]. Albeit also binding to the amino-terminal region of $\mathrm{A} \beta 42, \mathrm{PaD} 172-\mathrm{F} 12$ exhibited no substantial effect on fibril formation. With no major discrepancies in the affinity compared to PaD97-D6 or PaD236-H2, this result is likely to be accounted to the minute differences in epitopes. It is plausible that PaD172-F12 attaches to monomers in such way that no steric hindrance is administered towards the core region of A 342 . A partial masking of that area by an antibody would minimize monomer-monomer interaction and impede fibril formation. Epitope mapping demonstrates that PaD97-D6 binds $\mathrm{A} \beta_{1-13}$ while PaD172-F12 and PaD236-H2 bound further downstream $\left(\mathrm{A} \beta_{4-13}\right.$ for PaD172-F12 and $\mathrm{A} \beta_{5-13}$ for PaD236-H2). Obviously, PaD97-D6, PaD172-F12 and $\mathrm{PaD} 236-\mathrm{H} 2$ attach to the monomer with different spatial arrangements. Further, the region of the epitope on the $A \beta 42$ peptide may contribute to the similar $K_{D}$ values to different aggregates measured for these antibodies. PaD97-D6, PaD172-F12 and PaD236-H2 bind to the amino-terminal end of the $\beta$-amyloid peptide, an epitope that is exposed in monomers and aggregates during fibrillogenesis [54]. This may allow nearly equal affinities of the before mentioned antibodies to all three forms.

PaD233-E5 impacts fibril formation, which is not surprising as it targets the central region of $A \beta 42$ with $A \beta_{17-22}$ (LVFFAE), a part of the hydrophobic core element (LVFF) that is essential for $\beta$-sheet formation during fibrillization [65]. Together with the elevated affinity towards A $\beta 42$ monomers, this effect can be accounted to two probable modes of action or a mixture of both. PaD233-E5 either masks the LVFF-motif thus directly preventing monomer-monomer interaction. This effect was postulated by Legleiter et al. for the antibody $\mathrm{m} 266$, the murine progenitor of Solanezumab [61]. m266 targets the same epitope as PaD233-E5, binding to $\mathrm{A} \beta_{16-24}$ (KLFFAEDV) [66] and prevents the formation of fibrils and even protofibrils. The other possible explanation is the attachment of PaD233-E5 to A 342 monomers thus shifting the concentration threshold of soluble $\beta$-amyloid beneath the critical limit necessary for the polymerization process. Interestingly, PaD233-E5 has a much more pronounced influence on amyloid- $\beta$ fibrillogenesis than any other antibody as visualized by TEM. Yet the ThT absorbance after $96 \mathrm{~h}$ is 
A

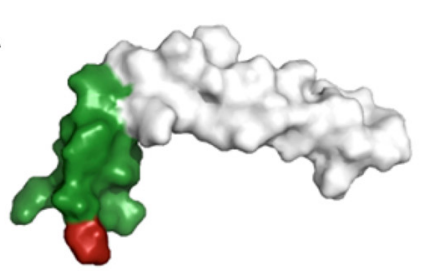

B
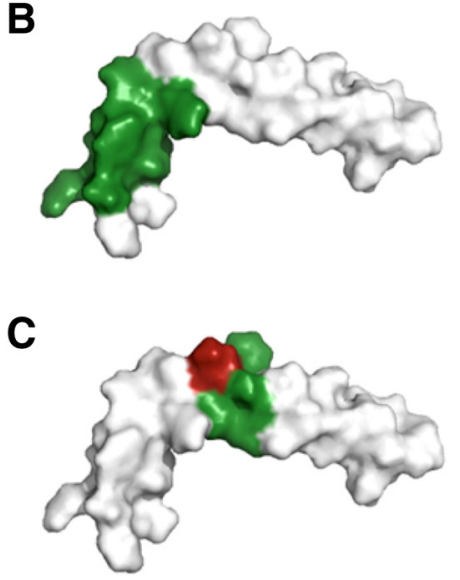

D

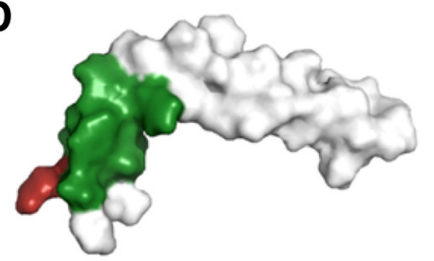

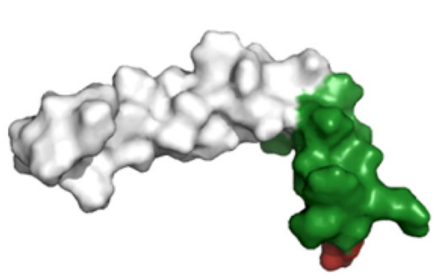
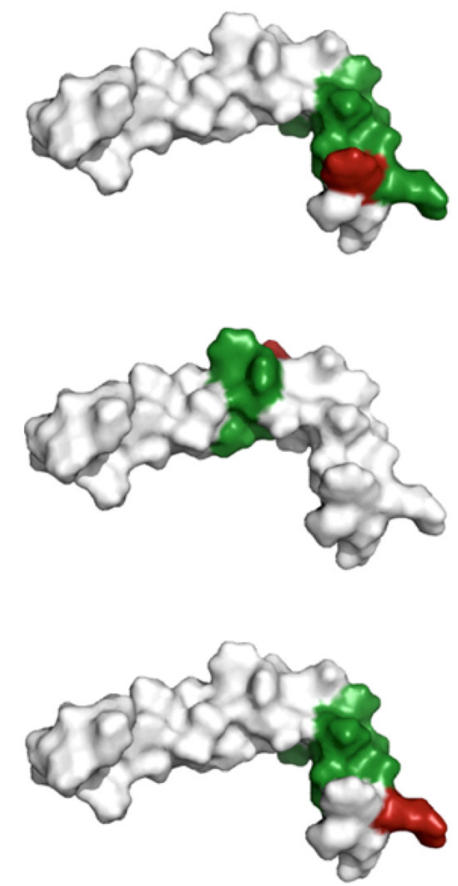

Figure 5 Visualization of the epitopes on A 42 on PDB structure 1zOq (Aß42 monomer in aqueous solution, [78]). Left, right: same molecule rotated by $180^{\circ}$ horizontally. Areas of the potential epitopes for (A) PaD97-D6, (B) PaD172-F12, (C) PaD233-E5 and (D) PaD236-H2 are colored green, the first amino acid of each epitope is colored red to facilitate recognition.

similar to that of $\mathrm{PaD} 236-\mathrm{H} 2$ which might be an indication for the formation of smaller aggregates with a $\beta$-sheet rich content. This would suggest the latter mode of action described for PaD233-E5 to be more dominant in the inhibition process.

The impact on $\mathrm{AD}$ immunotherapy of the antibodies presented in this work has to be further validated. Recently, Bapineuzumab (directed against the $\mathrm{N}$-terminus of $\mathrm{A} \beta$ ) and Solanezumab (directed against the central region

Table 2 Affinity determination by SPR

\begin{tabular}{llll}
\hline & \multicolumn{3}{l}{$\mathbf{K}_{\mathbf{D}}[\mathbf{M}]$ on $\mathbf{A} \boldsymbol{\beta} 42$ antigen } \\
\cline { 2 - 4 } Antibody & Monomers $\left(\boldsymbol{X}^{\mathbf{2}}\right)$ & Protofibrils $\left(\boldsymbol{X}^{\mathbf{2}}\right)$ & Fibrils $\left(\boldsymbol{X}^{\mathbf{2}}\right)$ \\
\hline PaD97-D6 & $2.3 \times 10^{-6}(4.9 \%)$ & $4.2 \times 10^{-6}(2.4 \%)$ & $9.1 \times 10^{-7}(2.3 \%)$ \\
PaD172-F12 & $9.4 \times 10^{-7}(2.4 \%)$ & $1.5 \times 10^{-6}(1.7 \%)$ & $9.2 \times 10^{-7}(2.4 \%)$ \\
PaD213-A5 & No binding & No binding & $3.7 \times 10^{-6}(1.1 \%)$ \\
PaD233-E5 & $1.0 \times 10^{-8}(6.6 \%)$ & $3.6 \times 10^{-6}(1.4 \%)$ & $1.2 \times 10^{-6}(1.4 \%)$ \\
PaD236-H2 & $3.5 \times 10^{-7}(2.5 \%)$ & $5.8 \times 10^{-7}(1.9 \%)$ & $6.2 \times 10^{-7}(5.7 \%)$ \\
\hline
\end{tabular}

$\mathrm{Chi}^{2}\left(\mathrm{X}^{2}\right)$ values are indicated in brackets. of $A \beta)$, both not conformation specific antibodies, failed to meet the expected endpoints in clinical phase 3 studies albeit having shown positive results in preceding studies (reviewed in [67]). The results of the initial characterization for the Yumabs in this work are promising. Especially PaD213-A5 exhibits a highly interesting property of differentiating between $A \beta 42$ fibrils based on their conformation that is not yet described in literature and its implication on $\mathrm{AD}$ diagnosis and therapy has to be further validated with in vivo data.

\section{Conclusion}

Among the investigated antibody fragments we found three scFvs exhibiting a general specificity towards $\beta$ amyloid while two scFvs, PaD213-A5 and PaD233-E5, presented a tendency to better bind to certain forms of $\mathrm{A} \beta 42 . \mathrm{PaD} 213-\mathrm{A} 5$ is highly specific for mature $\mathrm{A} \beta 42$ fibrils and identified a novel structural variation in fibrillar structures. PaD233-E5, albeit binding also oligomers and fibrils, showed a 100 fold increased affinity towards 


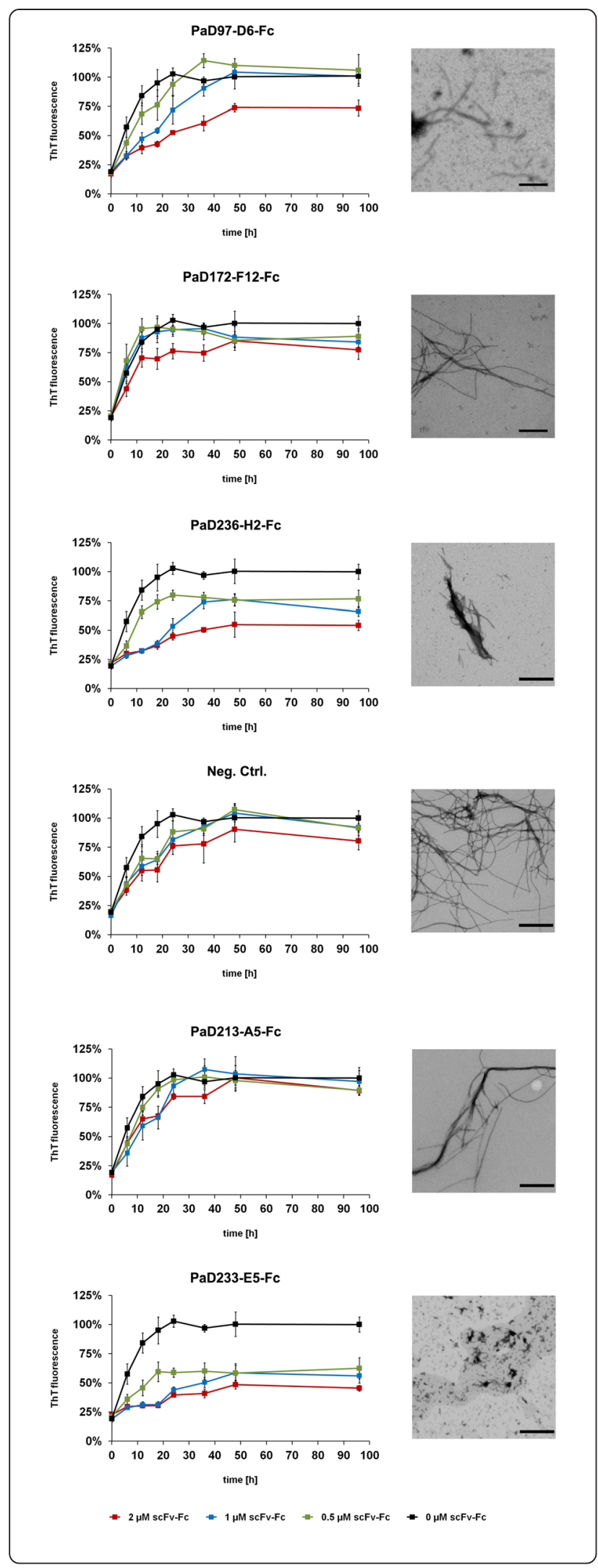

Figure 6 Influence of scFv-Fc antibodies (Yumabs) on $A \beta 42$ fibrillogenesis. Left: $5 \mu \mathrm{M}$ A 42 monomers were incubated with $2 \mu \mathrm{M}$ (red), $1 \mu \mathrm{M}$ (blue), $0.5 \mu \mathrm{M}$ (green) or $0 \mu \mathrm{M}$ (black) of scFv-Fc antibodies at $37^{\circ} \mathrm{C}$ under constant agitation of $300 \mathrm{rpm}$, ThT fluorescence was monitored over a time course of $96 \mathrm{~h}$. All measurements were carried out in triplicates, the error bars represent the respective standard deviation. Right: representative TEM images of the fibrils formed from of $5 \mu \mathrm{M} A \beta 42$ monomer after $96 \mathrm{~h}$ incubation in the presence of $2 \mu \mathrm{M}$ scFv-Fc antibody, scale bar corresponds to $400 \mathrm{~nm}$.

monomers. It is also one of the three antibodies exhibiting an inhibitory effect on the fibrillization of $A \beta 42$ monomers.

While the in vivo relevance of these differences is still to be established, the study confirms that the approach of animal immunization and subsequent phage display based antibody selection is applicable to generate highly specific anti $\beta$-amyloid scFvs that are capable of accurately discriminating between minute conformational differences.

\section{Methods}

Antigen preparation

A $\beta 42$ peptides were synthesized by Dr. James I. Elliott at Yale University (New Haven) [68]. All A 342 antigens, including monomers, protofibrils and different size oligomers derived thereof by further fractionation as well as Fibrils were prepared according to $[18,69]$.

\section{TEM sample grid preparation and image acquisition}

5-10 $\mu \mathrm{L}$ of sample was deposited on a formvar coated 200 mesh TEM grid (EM Science, Hatfield) and incubated for $1 \mathrm{~min}$. Excess fluids were wicked away with a piece of filter paper. The grid was washed twice by applying $10 \mu \mathrm{L}$ of $\mathrm{dH}_{2} \mathrm{O}$ before incubating the sample twice with $10 \mu \mathrm{L}$ of $2 \%(\mathrm{w} / \mathrm{v})$ uranyl acetate for 1 minute each. The grid was dried with a vacuum pump, incubated for $5 \mathrm{~min}$ at room temperature to completely dry off and stored in the designed container. Imaging was carried out on a Tecnai G2 Spirit microscope at an acceleration voltage of $80 \mathrm{kV}$.

\section{Ethics statement and animal care}

All animal studies presented were given specific approval from the Institut de Recherche Biomédicale des Armées ethics committee (Comité d'éthique de l'Institut de Recherche Biomédicale du Service de Santé des Armées) under authorization no. 2008/03.0 and were performed in accordance with all relevant French laws and ethical guidelines, including, in particular (i) "partie règlementaire du livre II du code rural (Titre I, chapitre IV, section 5, sous-section 3: expérimentation sur l'animal)", (ii) "décret 87-848 du 19-10/1987 relatif aux expériences pratiquées sur les animaux vertébrés modifié par le décret 2001/464 du 29/05/2001", (iii) "arrêté du 29 
octobre 1990 relatif aux conditions de l'expérimentation animale pour le Ministère de la Défense" and (iv) "instruction 844/DEF/DCSSA/AST/VET du 9 avril 1991 relative aux conditions de réalisation de l'expérimentation animale".

Animal care procedures complied with the regulations detailed under the Animal Welfare Act [70] and in the Guide for the Care and Use of Laboratory Animals [71]. Animals were kept at a constant temperature $\left(22^{\circ} \mathrm{C}+/-2^{\circ} \mathrm{C}\right)$ and relative humidity (50\%), with 12 hours of artificial light per day. They were housed in individual cages (6 per room), each of which contained a perch. Animals were fed twice daily, once with dried food and once with fresh fruits and vegetables, and water was provided at the same time. Food intake and general behavior were observed by animal technicians during feeding times, and veterinary surgeons were available for consultation if necessary. Veterinary surgeons also carried out systematic visits to each NHProom twice weekly. The environmental enrichment program for the nonhuman primates was limited to games with animal care staff and access to approved toys. The well-being of the animals was monitored by the attending veterinary surgeon. Animals were anesthetized before the collection of blood or bone marrow by an intramuscular injection of $10 \mathrm{mg} / \mathrm{kg}$ ketamine (Imalgene ${ }^{\circ}$, Merial, Lyon, France). Analgesics were subsequently administered, through a single intramuscular injection of $5 \mathrm{mg} / \mathrm{kg}$ flunixine (Finadyne ${ }^{\circ}$, Schering Plough, Courbevoie, France) in the days after interventions if the animal technicians suspected that the animal was in pain, on the basis of their observations of animal behavior. None of the nonhuman primates were killed during this study.

\section{Animal immunization}

A male macaque (Macaca fascicularis) was immunized with a total of 6 subcutaneous injections of purified and sterile filtered small oligomers of $A \beta 42$. Injections were carried out with $50 \mu \mathrm{g}$ antigen (inj. 1-3) and $50 \mu \mathrm{g}$ antigen (inj. 4-6) at a one month interval, except for the sixth injection which was given 2 months after the fifth.

\section{Construction of the anti $A \beta 42 \mathrm{scFv}$ phage display library}

Six and nine days respectively after the last boost, RNA was isolated using Tri Reagent (Molecular Research Center Inc, Cincinnati, USA) from the bone marrow of the immunized macaque and transferred into cDNA by reverse transcription. DNA was amplified by PCR using seven different oligonucleotide primers for the coding regions of the light chain and nine different primers for the heavy chain [72]. After amplification, PCR products were pooled and subcloned into pGemT (Promega, Madison, Wisconsin). Antibody inserts in pGemT were re-amplified with individual primer sets for the kappa (к) and lambda $(\lambda)$ sublibraries introducing specific restriction sites for the cloning of the final library as described [44]. Library packaging was carried out using M13K07 as helperphage.

\section{Selection of recombinant antibodies against $A \beta 42$}

ScFvs were isolated in vitro by panning the macaque derived immune libraries as well as the human naïve libraries HAL7/8 [44] as described previously [73]. Antigen coating was carried out at $4^{\circ} \mathrm{C}$ overnight in $100 \mathrm{mM}$ $\mathrm{Na}$-Borate buffer and constant amounts $(1 \mu \mathrm{g})$ of antigen were used as bait during the three panning rounds. To increase the possibility of obtaining antibodies specific for one A $\beta 42$ conformation, competition with unwanted conformations of $\mathrm{A} \beta 42$ was done using $3 \mu \mathrm{g}$ of antigen or $5 \mu \mathrm{g}$ for A $\beta 42$ fibrils respectively. Individual colonies of bacteria infected with eluted antibody phage were isolated and inoculated in MTP (microtiter plate) wells to produce soluble antibody fragments as described previously [74]. The produced scFvs were analyzed for specific binding by ELISA on diverse aggregates of $A \beta 42$, corresponding to the panning.

\section{Enzyme linked immunosorbent assay (ELISA)}

Two kinds of ELISA (screening ELISA, antigen titration ELISA) were performed as described before [74]. In both cases a total of $100 \mathrm{ng}$ of antigen per cavity was coated in 96well MTPs (High Binding, Costar) at $4^{\circ} \mathrm{C}$ overnight. All following steps were carried out at room temperature on a rocker. For screening, scFvs were detected by $\mathrm{mAb}$ 9E10, recognizing the c-myc tag and a goat anti-mouse antibody conjugated to horseradish peroxidase (Sigma A0168). For titration, scFvs were detected by a mouse anti penta-His (34660, Qiagen), recognizing the His tag and a goat anti-mouse antibody conjugated to horseradish peroxidase (A0168, Sigma Aldrich). Bound scFv-Fc antibodies were detected using a peroxidase-labeled goat anti-human antibody recognizing the Fc fragment (A0170, SigmaAldrich).

\section{ScFv and scFv-Fc antibody production and purification}

The scFv inserts of positive clones were subcloned into the pCSE2.5-HIS-XP and the pCSE2.5-hIgG1-Fc-XP vector, and the resulting scFv or scFv-Fc antibodies (Yumabs) were transiently produced in HEK293-6E cells [75] as described previously [45]. The cultivation medium was chemically defined F17 medium (Invitrogen, Life Technologies) supplemented with $7.5 \mathrm{mM}$ L-glutamine, 0.1\% PF68 (Applichem) and 1\% Penicillin/Streptomycine. Antibody fragments were purified using immobilized metal ion $\left(\mathrm{Ni}^{2+}\right)$ or protein A affinity chromatography on the Profinia ${ }^{\text {m }}$ Affinity Chromatography Protein Purification System (BioRad), according to the manufacturer's protocol. 


\section{Thioflavin T (ThT) measurements}

To assess the state of fibrillogenesis by Thioflavin $T$ (ThT) measurement, $20 \mu \mathrm{L}$ of sample was mixed with $10 \mu \mathrm{L}$ of ThT $(100 \mu \mathrm{M})$ and $70 \mu \mathrm{L}$ of glycine $\mathrm{NaOH}$, pH 8.5 (500 mM) in a well of a black 384-well Nunc plate (Sigma-Aldrich). Fluorescence was measured in triplicates on an Analyst ${ }^{\mathrm{Tm}} \mathrm{AD}$ fluorometer (Molecular Devices Cooperation) at an excitation wavelength of $\lambda=450 \mathrm{~nm}$ and emission wavelength of $\lambda=485 \mathrm{~nm}$.

\section{Epitope mapping}

The peptide sequence of A $\beta 42$ was divided into overlapping peptide fragments of 15 aa length with an offset of 1 aa. The N-terminus was acetylated and two additional glycines were added to the sequence to allow for proper binding of the antibodies to the aspartic acid, the first aa of A 342 . The peptides were synthesized by the SPOT technique $[76,77]$ and covalently bound to a continuous cellulose membrane via their carboxy-terminus (JPT Peptide Technologies $\mathrm{GmbH}$ ). After initial incubation for $5 \mathrm{~min}$ in methanol to prevent the precipitation of hydrophobic peptides the membrane was rinsed with 1xTBS (50 mM TRIS, $137 \mathrm{mM} \mathrm{NaCl}, 2.7 \mathrm{mM} \mathrm{KCl}, \mathrm{pH}$ adjusted to 8.0 with $\mathrm{HCl}$ ) and blocked in $2 \%(\mathrm{w} / \mathrm{v})$ skim milk powder in $1 \mathrm{xTBS}(2 \%$ M-TBS) for $1 \mathrm{~h}$ at room temperature on a rocker. ScFv-Fc antibodies $(10 \mu \mathrm{g} / \mathrm{mL}$ in $2 \% \mathrm{M}$-TBS $)$ were incubated on the membranes for $1.5 \mathrm{~h}$ at room temperature. Bound antibodies were detected by using a peroxidase-labeled goat anti-human antibody recognizing the Fc fragment (A0170, Sigma-Aldrich). Development with SuperSignal West Pico Chemiluminescent Substrate (Thermo Scientific) according to manufacturer's protocol on a ChemiDoc ${ }^{\mathrm{Ts}}$ MP system (BioRad).

\section{Affinity measurement}

Antibody affinities were analyzed by surface plasmon resonance (SPR) using a BIAcore2000 ${ }^{\mathrm{ms}}$. A $\beta 42$ monomers and protofibrils were immobilized on separate CM5 chips (General Electric-Biacore), fibrils were immobilized on a CMD50m chip (Xantec) via amine coupling according to the manufacturers protocols. ScFvs were diluted to 100 $\mathrm{nM}-10,000 \mathrm{nM}$ (additionally to 15,000 nM for PaD97-D6 and 15,000 $\mathrm{nM}+20,000 \mathrm{nM}$ for PaD213-A5) and added to the chips in HBS-EP buffer according to the manufacturer's protocol at a flow rate of $25 \mu \mathrm{L} / \mathrm{min}$. Timeframes were $200 \mathrm{~s}$ for association and $600 \mathrm{~s}$ for dissociation. After each dilution, the chip was regenerated with $\mathrm{NaOH}$ according to the manufacturer's protocol. Data fitting was performed using the "1:1 binding with drifting baseline"

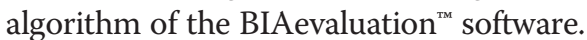

\section{Abbreviations}

aa: Amino acid; $A \beta$ : Amyloid- $\beta / \beta$-amyloid; AD: Alzheimer's disease; NHP: Non human primate; scFv: Single chain fragment variable; Fc: Fragment crystallizable; TEM: Transmission electron microscopy; ThT: Thioflavin T.

\section{Competing interests}

The authors declare that they have no competing interests.

\section{Authors' contributions}

PD performed experiments, analyzed data and drafted the manuscript. AF, MS, TP performed experiments and analyzed data. PT and MH participated in the design of the study, analyzed data and drafted the manuscript. $\mathrm{HL}$ and SD conceived the project, participated in the design and coordination of the study, analyzed data and drafted the manuscript. All authors read and approved the final manuscript.

\section{Acknowledgements}

We gratefully acknowledge the support of this work by the Strauss Foundation and the European Research Council (ERC grant number 243182).

\section{Author details}

'Technische Universität Braunschweig, Institute of Biochemistry, Biotechnology and Bioinformatics, Spielmannstr.7, 38106 Braunschweig, Germany. ${ }^{2}$ Current address: Celerion Switzerland AG, Allmendstrasse 32, 8320 Fehraltorf, Switzerland. ${ }^{3}$ YUMAB GmbH, Rebenring 33, 38106 Braunschweig, Germany. ${ }^{4}$ Current address: Delenex Therapeutics AG, Wagistrasse 27, 8952 Schlieren, Switzerland. ${ }^{5}$ Institut de recherche Biomédicale des Armées (IRBA-CRSSA); Département de Microbiologie; Unité de biotechnologie des anticorps et des toxines, La Tronche Cedex, France. ${ }^{6}$ Current address: BIOTEM Parc d'Activités Bièvre Dauphine, 885, rue Alphonse Gourju, 38140 Apprieu, France. ${ }^{7}$ SV-BMI, Laboratory of Molecular and Chemical Biology of Neurodegeneration, Brain Mind Institute, École Polytechnique Fédérale de Lausanne, Station 19, 1015 Lausanne, Switzerland.

Received: 27 November 2014 Accepted: 20 April 2015

Published online: 18 June 2015

\section{References}

1. Fitzpatrick $A L$, Kuller $L H$, Lopez OL, Kawas $C H$, Jagust W. Survival following dementia onset: Alzheimer's disease and vascular dementia. J Neurol Sci. 2005;229-230:43-9.

2. Goedert M, Wischik CM, Crowther RA, Walker JE, Klug A. Cloning and sequencing of the CDNA encoding a core protein of the paired helical filament of Alzheimer disease: identification as the microtubule-associated protein tau. Proc Natl Acad Sci U S A. 1988;85:4051-5.

3. Kosik KS, Joachim CL, Selkoe DJ. Microtubule-associated protein tau (tau) is a major antigenic component of paired helical filaments in Alzheimer disease. Proc Natl Acad Sci U S A. 1986;83:4044-8.

4. Glenner GG, Wong CW. Alzheimer's disease: initial report of the purification and characterization of a novel cerebrovascular amyloid protein. Biochem Biophys Res Commun. 1984;120:885-90.

5. Masters CL, Multhaup G, Simms G, Pottgiesser J, Martins RN, Beyreuther K. Neuronal origin of a cerebral amyloid: neurofibrillary tangles of Alzheimer's disease contain the same protein as the amyloid of plaque cores and blood vessels. EMBO J. 1985;4:2757-63.

6. Selkoe DJ, Abraham CR, Podlisny MB, Duffy LK. Isolation of low-molecular-weight proteins from amyloid plaque fibers in Alzheimer's disease. J Neurochem. 1986;46:1820-34

7. Seubert P, Vigo-Pelfrey C, Esch F, Lee M, Dovey H, Davis D, et al. Isolation and quantification of soluble Alzheimer's beta-peptide from biological fluids. Nature. 1992;359:325-7.

8. Harper JD, Lansbury Jr PT. Models of amyloid seeding in Alzheimer's disease and scrapie: mechanistic truths and physiological consequences of the time-dependent solubility of amyloid proteins. Annu Rev Biochem. 1997;66:385-407.

9. Jarrett JT, Berger EP, Lansbury Jr PT. The carboxy terminus of the. beta. amyloid protein is critical for the seeding of amyloid formation: Implications for the pathogenesis of Alzheimer's disease. Biochemistry (Mosc). 1993;32:4693-7.

10. Garzon-Rodriguez W, Sepulveda-Becerra M, Milton S, Glabe CG. Soluble Amyloid $A \beta-(1-40)$ exists as a stable dimer at low concentrations. J Biol Chem. 1997;272:21037-44.

11. Roher AE, Chaney MO, Kuo Y-M, Webster SD, Stine WB, Haverkamp LJ, et al. Morphology and toxicity of A $\beta-(1-42)$ dimer derived from neuritic and vascular Amyloid deposits of Alzheimer's disease. J Biol Chem. 1996;271:20631-5. 
12. Bitan G, Fradinger EA, Spring SM, Teplow DB. Neurotoxic protein oligomers-what you see is not always what you get. Amyloid Int J Exp Clin Investig Off J Int Soc Amyloidosis. 2005;12:88-95.

13. Cleary JP, Walsh DM, Hofmeister JJ, Shankar GM, Kuskowski MA, Selkoe DJ, et al. Natural oligomers of the amyloid-beta protein specifically disrupt cognitive function. Nat Neurosci. 2005;8:79-84

14. Dahlgren KN. Oligomeric and fibrillar species of Amyloid-beta peptides differentially affect neuronal viability. J Biol Chem. 2002;277:32046-53.

15. Lesné S, Koh MT, Kotilinek L, Kayed R, Glabe CG, Yang A, et al. A specific amyloid- $\beta$ protein assembly in the brain impairs memory. Nature. 2006;440:352-7.

16. Walsh DM, Klyubin I, Fadeeva JV, Cullen WK, Anwyl R, Wolfe MS, et al, Naturally secreted oligomers of amyloid beta protein potently inhibit hippocampal long-term potentiation in vivo. Nature. 2002;416:535-9.

17. Walsh DM, Lomakin A, Benedek GB, Condron MM, Teplow DB. Amyloid $\beta$-protein fibrillogenesis detection of a protofibrillar intermediate. J Biol Chem. 1997;272:22364-72.

18. Jan A, Adolfsson O, Allaman I, Buccarello A-L, Magistretti PJ, Pfeifer A, et al. A 342 Neurotoxicity is mediated by ongoing nucleated polymerization process rather than by discrete A 42 species. J Biol Chem. 2010;286:8585-96.

19. Ahmed M, Davis J, Aucoin D, Sato T, Ahuja S, Aimoto S, et al. Structural conversion of neurotoxic amyloid- $\beta(1-42)$ oligomers to fibrils. Nat Struct Mol Biol. 2010;17:561-7.

20. Benilova I, Karran E, De Strooper B. The toxic A oligomer and Alzheimer's disease: an emperor in need of clothes. Nat Neurosci. 2012;15:349-57.

21. Haass C, Selkoe DJ. Soluble protein oligomers in neurodegeneration: lessons from the Alzheimer's amyloid $\beta$-peptide. Nat Rev Mol Cell Biol. 2007;8:101-12

22. Kayed R, Head E, Thompson JL, McIntire TM, Milton SC, Cotman CW, et al. Common structure of soluble amyloid oligomers implies common mechanism of pathogenesis. Science. 2003;300:486-9.

23. Kim T, Vidal GS, Djurisic M, William CM, Birnbaum ME, Garcia KC, et al. Human LilrB2 Is a $\beta$-Amyloid Receptor and Its Murine Homolog PirB Regulates Synaptic Plasticity in an Alzheimer's Model. Science. 2013;341:1399-1404.

24. Lambert MP, Barlow AK, Chromy BA, Edwards C, Freed R, Liosatos M, et al. Diffusible, nonfibrillar ligands derived from Abeta1-42 are potent central nervous system neurotoxins. Proc Natl Acad Sci U S A. 1998;95:6448-53.

25. Walsh DM, Klyubin I, Fadeeva JV, Rowan MJ, Selkoe DJ. Amyloid-beta oligomers: their production, toxicity and therapeutic inhibition. Biochem Soc Trans. 2002;30:552-7.

26. Nelson PT, Braak H, Markesbery WR. Neuropathology and cognitive impairment in Alzheimer disease: a complex but coherent relationship. J Neuropathol Exp Neurol. 2009;68:1-14.

27. Fox NC, Freeborough PA, Rossor MN. Visualisation and quantification of rates of atrophy in Alzheimer's disease. Lancet. 1996;348:94-7.

28. Johnson KA, Fox NC, Sperling RA, Klunk WE. Brain imaging in Alzheimer disease. Cold Spring Harb Perspect Med. 2012;2:a006213.

29. Marshall GA, Monserratt L, Harwood D, Mandelkern M, Cummings JL, Sultzer DL. Positron emission tomography metabolic correlates of apathy in Alzheimer disease. Arch Neurol. 2007;64:1015-20.

30. Shaw LM, Vanderstichele H, Knapik-Czajka M, Clark CM, Aisen PS, Petersen RC, et al. Cerebrospinal fluid biomarker signature in Alzheimer's disease neuroimaging initiative subjects. Ann Neurol. 2009;65:403-13.

31. Buckholtz NS. Perspective: in search of biomarkers. Nature. 2011;475:S8.

32. Colledge NR, Walker BR, Ralston S, Davidson S. Davidson's principles and practice of medicine. Edinburgh; New York: Churchill Livingstone/Elsevier; 2010.

33. Doody RS. Therapeutic standards in Alzheimer disease. Alzheimer Dis Assoc Disord. 1999;13 Suppl 2:S20-6.

34. Ferris $\mathrm{SH}$. Evaluation of memantine for the treatment of Alzheimer's disease. Expert Opin Pharmacother. 2003:4:2305-13.

35. Pelat $T$, Hust M, Hale M, Lefranc M-P, Dübel $S$, Thullier $P$. Isolation of a human-like antibody fragment (scFv) that neutralizes ricin biological activity. BMC Biotechnol. 2009;9:60.

36. Laffly E, Danjou L, Condemine F, Vidal D, Drouet E, Lefranc M-P, et al. Selection of a Macaque Fab with framework regions like those in humans, high affinity, and ability to neutralize the Protective Antigen (PA) of Bacillus anthracis by binding to the segment of PA between residues 686 and 694. Antimicrob Agents Chemother. 2005;49:3414-20.

37. Pelat T, Hust M, Laffly E, Condemine F, Bottex C, Vidal D, et al. High-affinity, human antibody-like antibody fragment (Single-Chain Variable Fragment) neutralizing the Lethal Factor (LF) of Bacillus anthracis by inhibiting protective Antigen-LF complex formation. Antimicrob Agents Chemother. 2007;51:2758-64.

38. Schütte $M$, Thullier $P$, Pelat $T$, Wezler $X$, Rosenstock $P$, Hinz D, et al Identification of a putative Crf splice variant and generation of recombinant antibodies for the specific detection of Aspergillus fumigatus. PLoS One. 2009;4:e6625.

39. Rülker T, Voß L, Thullier P, O' Brien LM, Pelat T, Perkins SD, et al. Isolation and characterisation of a human-like antibody fragment (scFv) that inactivates VEEV in vitro and in vivo. PLoS One. 2012;7, e37242.

40. Hülseweh B, Rülker T, Pelat T, Langermann C, Frenzel A, Schirrmann T, et al. Human-like antibodies neutralizing Western equine encephalitis virus. mAbs. 2014;6:718-27.

41. Miethe S, Rasetti-Escargueil C, Liu Y, Chahboun S, Pelat T, Avril A, et al. Development of neutralizing scFv-Fc against botulinum neurotoxin A light chain from a macaque immune library. mAbs. 2014;6:446-59.

42. Avril A, Froude J, Mathieu J, Pelat T, Thullier P. Isolation of antibodies from Non-human primates for clinical use. Curr Drug Discov Technol. 2014;11:20-7.

43. Bradbury ARM, Sidhu S, Dübel S, McCafferty J. Beyond natural antibodies: the power of in vitro display technologies. Nat Biotechnol. 2011;29:245-54.

44. Hust M, Meyer T, Voedisch B, Rülker T, Thie H, El-Ghezal A, et al. A human scFv antibody generation pipeline for proteome research. J Biotechnol. 2011;152:159-70.

45. Jäger V, Büssow K, Wagner A, Weber S, Hust M, Frenzel A, et al. High level transient production of recombinant antibodies and antibody fusion proteins in HEK293 cells. BMC Biotechnol. 2013;13:52.

46. Lee M, Bard F, Johnson-Wood K, Lee C, Hu K, Griffith SG, et al. Aß42 immunization in Alzheimer's disease generates $A \beta \mathrm{N}$-terminal antibodies. Ann Neurol. 2005;58:430-5

47. Lemere CA, Beierschmitt A, Iglesias M, Spooner ET, Bloom JK, Leverone JF, et al. Alzheimer's disease $A \beta$ vaccine reduces central nervous system $A \beta$ levels in a non-human primate, the Caribbean Vervet. Am J Pathol. 2004;165:283-97.

48. Vasilevko V, Pop V, Kim HJ, Saing T, Glabe CC, Milton S, et al. Linear and conformation specific antibodies in aged beagles after prolonged vaccination with aggregated Abeta. Neurobiol Dis. 2010;39:301-10.

49. Bard F, Barbour R, Cannon C, Carretto R, Fox M, Games D, et al. Epitope and isotype specificities of antibodies to beta -amyloid peptide for protection against Alzheimer's disease-like neuropathology. Proc Natl Acad Sci U S A. 2003;100:2023-8

50. Miller DL, Currie JR, Mehta PD, Potempska A, Hwang Y-W, Wegiel J. Humoral immune response to fibrillar beta-amyloid peptide. Biochemistry (Mosc). 2003:42:11682-92.

51. Bacskai BJ, Kajdasz ST, McLellan ME, Games D, Seubert P, Schenk D, et al. Non-Fc-mediated mechanisms are involved in clearance of amyloid-beta in vivo by immunotherapy. J Neurosci Off J Soc Neurosci. 2002;22:7873-8.

52. Dornieden S, Müller-Schiffmann A, Sticht H, Jiang N, Cinar Y, Wördehoff M, et al. Characterization of a single-chain variable fragment recognizing a linear epitope of $A \beta$ : a biotechnical tool for studies on Alzheimer's disease? PLoS ONE. 2013;8:e59820.

53. Howlett DR, Perry AE, Godfrey F, Swatton JE, Jennings KH, Spitzfaden C, et al. Inhibition of fibril formation in beta-amyloid peptide by a novel series of benzofurans. Biochem J. 1999;340:283-9.

54. Ida N, Hartmann T, Pantel J, Schröder J, Zerfass R, Förstl H, et al. Analysis of heterogeneous A4 peptides in human cerebrospinal fluid and blood by a newly developed sensitive Western blot assay. J Biol Chem. 1996;271:22908-14.

55. Johnson-Wood K, Lee M, Motter R, Hu K, Gordon G, Barbour R, et al. Amyloid precursor protein processing and $A \beta 42$ deposition in a transgenic mouse model of Alzheimer disease. Proc Natl Acad Sci U S A. 1997;94:1550-5.

56. Meinhardt J, Sachse C, Hortschansky P, Grigorieff N, Fändrich M. Abeta(1-40) fibril polymorphism implies diverse interaction patterns in amyloid fibrils. J Mol Biol. 2009;386(3):869-77.

57. Habicht G, Haupt C, Friedrich RP, Hortschansky P, Sachse C, Meinhardt J, et al. Directed selection of a conformational antibody domain that prevents mature amyloid fibril formation by stabilizing $A \beta$ protofibrils. Proc Natl Acad Sci. 2007;104:19232-7.

58. Kayed R, Head E, Sarsoza F, Saing T, Cotman CW, Necula M, et al. Fibril specific, conformation dependent antibodies recognize a generic epitope common to amyloid fibrils and fibrillar oligomers that is absent in prefibrillar oligomers. Mol Neurodegener. 2007;2:18.

59. O'Nuallain B, Wetzel R. Conformational Abs recognizing a generic amyloid fibril epitope. Proc Natl Acad Sci. 2002;99:1485-90. 
60. Frenkel D, Katz O, Solomon B. Immunization against Alzheimer's $\beta$-amyloid plaques via EFRH phage administration. Proc Natl Acad Sci U S A. 2000;97:11455-9.

61. Legleiter J, Czilli DL, Gitter B, DeMattos RB, Holtzman DM, Kowalewski T. Effect of different Anti-A $\beta$ antibodies on $A \beta$ Fibrillogenesis as assessed by atomic force microscopy. J Mol Biol. 2004;335:997-1006.

62. McLaurin J, Cecal R, Kierstead ME, Tian X, Phinney AL, Manea M, et al. Therapeutically effective antibodies against amyloid-beta peptide target amyloid-beta residues 4-10 and inhibit cytotoxicity and fibrillogenesis. Nat Med. 2002;8:1263-9.

63. Robert R, Dolezal O, Waddington L, Hattarki MK, Cappai R, Masters CL, et al. Engineered antibody intervention strategies for Alzheimer's disease and related dementias by targeting amyloid and toxic oligomers. Protein Eng Des Sel. 2009;22:199-208.

64. Solomon B, Koppel R, Hanan E, Katzav T. Monoclonal antibodies inhibit in vitro fibrillar aggregation of the Alzheimer beta-amyloid peptide. Proc Natl Acad Sci U S A. 1996;93:452-5.

65. Hilbich C, Kisters-Woike B, Reed J, Masters CL, Beyreuther K. Substitutions of hydrophobic amino acids reduce the amyloidogenicity of Alzheimer's disease beta A4 peptides. J Mol Biol. 1992;228:460-73.

66. Moreth J, Mavoungou C, Schindowski K. Passive anti-amyloid immunotherapy in Alzheimer's disease: What are the most promising targets? Immun Ageing A. 2013;10:18.

67. Prins ND, Scheltens P. Treating Alzheimer's disease with monoclonal antibodies: current status and outlook for the future. Alzheimers Res Ther. 2013;5:56.

68. Sato T, Kienlen-Campard P, Ahmed M, Liu W, Li H, Elliott Jl, et al. Inhibitors of amyloid toxicity based on beta-sheet packing of Abeta40 and Abeta42. Biochemistry (Mosc). 2006;45:5503-16.

69. Jan A, Gokce O, Luthi-Carter R, Lashuel HA. The ratio of monomeric to aggregated forms of $A \beta 40$ and $A \beta 42$ is an important determinant of Amyloid- $\beta$ aggregation, fibrillogenesis, and toxicity. J Biol Chem. 2008;283:28176-89.

70. "USDA Animal Welfare Act (AWA). 7 U.S.C. 2131 et seq., as amended and Health Research Extension Act of 1985 ("'Animals in Research"'). 1985."

71. National Research Council (US) Committee for the Update of the Guide for the Care and Use of Laboratory Animals. Guide for the Care and Use of Laboratory Animals. 8th ed. Washington (DC): National Academies Press (US); 2011.

72. Pelat $\mathrm{T}$, Hust $\mathrm{M}$, Thullier $\mathrm{P}$. Obtention and engineering of non-human primate (NHP) antibodies for therapeutics. Mini Rev Med Chem. 2009;9:1633-8.

73. Frenzel A, Kügler J, Wilke S, Schirrmann T, Hust M. Construction of human antibody gene libraries and selection of antibodies by phage display. Methods Mol. Biol. Clifton NJ. 2014;1060:215-43.

74. Fuchs M, Kampfer S, Helmsing S, Spallek R, Oehlmann W, Prilop W, et al. Novel human recombinant antibodies against Mycobacterium tuberculosis antigen 85B. BMC Biotechnol. 2014;14:68.

75. Durocher $Y$, Perret S, Kamen A. High-level and high-throughput recombinant protein production by transient transfection of suspension-growing human 293-EBNA1 cells. Nucleic Acids Res. 2002;30:E9.

76. Frank R. Spot-synthesis: an easy technique for the positionally addressable, parallel chemical synthesis on a membrane support. Tetrahedron. 1992:48:9217-32.

77. Frank R. The SPOT-synthesis technique: synthetic peptide arrays on membrane supports-principles and applications. J Immunol Methods. 2002;267:13-26.

78. Tomaselli S, Esposito V, Vangone P, van Nuland NAJ, Bonvin AMJJ, Guerrini $R$, et al. The alpha-to-beta conformational transition of Alzheimer's Abeta-(1-42) peptide in aqueous media is reversible: a step by step conformational analysis suggests the location of beta conformation seeding. Chembiochem Eur J Chem Biol. 2006;7:257-67.

\section{Submit your next manuscript to BioMed Central and take full advantage of:}

- Convenient online submission

- Thorough peer review

- No space constraints or color figure charges

- Immediate publication on acceptance

- Inclusion in PubMed, CAS, Scopus and Google Scholar

- Research which is freely available for redistribution

Submit your manuscript at www.biomedcentral.com/submit 